\title{
Characterization of TiZrN and TaZrN Nanocomposite Multilayer Coating Deposited via RF/DC Magnetron Sputtering on AISI4140 Steel
}

\author{
R. Hariharan $\mathbb{D}^{1},{ }^{1}$ R. Raja, ${ }^{2}$ R. J. Golden Renjith Nimal, ${ }^{3}$ Mohamad Reda A. Refaai, ${ }^{4}$ S Ravi, ${ }^{5}$ \\ and Haiter Lenin Allasi ${ }^{6}{ }^{6}$ \\ ${ }^{1}$ Department of Mechanical Engineering, Bharath Institute of Higher Education and Research, Chennai-73, Tamilnadu, India \\ ${ }^{2}$ VPMM Engineering College for Women, Srivilliputhur 626190, Tamilnadu, India \\ ${ }^{3}$ Department of Mechanical Engineering, Jai Shriram Engineering College, Tirupur-638660, Tamilnadu, India \\ ${ }^{4}$ Prince Sattam Bin Abdulaziz University, College of Engineering Department of Mechanical Engineering, Alkharj 16273, \\ Saudi Arabia \\ ${ }^{5}$ Centre for Materials Research, Chennai Institute of Technology, Chennai 600069, Tamilnadu, India \\ ${ }^{6}$ Department of Mechanical Engineering, Wollo University Kombolcha Institute of Technology, Kombolcha, Ethiopia
}

Correspondence should be addressed to R. Hariharan; hariharan.mech@bharathuniv.ac.in and Haiter Lenin Allasi; drahlenin@kiot.edu.et

Received 28 September 2021; Revised 4 November 2021; Accepted 13 November 2021; Published 22 December 2021

Academic Editor: P Ganeshan

Copyright $\odot 2021$ R. Hariharan et al. This is an open access article distributed under the Creative Commons Attribution License, which permits unrestricted use, distribution, and reproduction in any medium, provided the original work is properly cited.

In this present research work, TiZrN and TaZrN multilayer coating was deposited on 4140 steel by RF/DC magnetron sputtering for comparative work also prepared in single layer. The flow rate ratio of $\mathrm{Ar} / \mathrm{N} 2$ was set to $15: 3 \mathrm{sccm}$ and the thin film was prepared by the PVD (physical vapor deposition) method by RF/DC magnetron using a Ti-Zr and Ta-Zr target with a purity of 99.99\%. The crystal structure, surface morphology microstructure, and component arrangements were explored by X-ray diffraction (XRD), scanning electron microscope (SEM), and atomic force microscopy (AFM). It has been found that the crystal structure, surface morphology, microstructure, and elemental composition of the membrane are strongly dependent on deposition parameters. It is mechanically characterized by corrosion and Vickers hardness. In AFM measurements, coarse cluster particles with increasing $\mathrm{Ti}$ and $\mathrm{Ta}$ values not only increase the average roughness (Ra) by $2.341 \mathrm{~nm}\left(200^{\circ} \mathrm{C}\right)$ and $2.951 \mathrm{~nm}\left(400^{\circ} \mathrm{C}\right)$ but also have a continuous average thickness which was shown to increase by $1.504 \mathrm{~nm}$ and $781.75 \mathrm{~nm}$. With the increase of hardness, the roughness decreases correspondingly. The TiZrN multilayer microhardness augmented to $314 \mathrm{GPa}$ at $200^{\circ} \mathrm{C}$ and $371 \mathrm{GPa}$ for $\mathrm{TaZrN}\left(400^{\circ} \mathrm{C}\right)$.

\section{Introduction}

There are various methods and processes for depositing TiZrN thin films, as most of them are made by a large applied arc current. However, the advantage of the deposition technology is that there is no additional request form, no polarized substrate, and a low temperature, which can reduce production time and thus manufacturing costs. The aim of this work was the deposition of nano structured thin TiZrN layers on unheated substrates without polarization of the substrate at different $\mathrm{Ti}$ sputtering currents with simultaneous asymmetrical DC magnetron sputtering [1-3]. The effect of the Ti sputtering current on the crystal structure morphology was analyzed.

Tantalum nitride is chemically inert, corrosion resistant, and hard. TaN thin films are thus gaining increasing attention for thin film resistors and diffusion barriers in the microelectronics industry. These films are known for their high temperature stability and their ability to resist oxidation up to $8000^{\circ} \mathrm{C}$. TaZrN coatings can resist oxidation up to $13000^{\circ} \mathrm{C}[4,5]$. There have been investigations carried out on the mechanical properties of $\mathrm{TaN}$ films, which clearly 
indicate their potential of being used as high hardness coatings. Some compounds present in $\mathrm{TaN}$ at high $\mathrm{N}_{2}$ flow and higher substrate temperature, such as orthorhombic $\mathrm{Ta} 4 \mathrm{~N}$ and FCC TaN have theoretical hardness of 61 and $50 \mathrm{GPa}$, respectively, although other researchers have reported the FCC phase to have hardness around $20 \mathrm{GPa}$.

On the other hand, when we use these two high-k materials individually, there was a problem with the electronic instabilities of zirconium oxide on Si substrate [6]. Eventually, there would be an unstable interface at $\mathrm{ZrO}_{2} / \mathrm{Si}$ stacks $\mathrm{TiO}_{2} / \mathrm{Si}$. Due to the very low offset of the conduction band, high leakage currents occur even at low temperatures. In order to accumulate the benefits of both oxide layers simultaneously in one device, we propose interface engineering that supports the chemical composition and physical structure of the titanium-doped zirconium oxide $\left(\mathrm{ZrTiO}_{2}\right)$ layer. $\mathrm{Zr}$-doped $\mathrm{TiO}_{2}$ thin films can be prepared by plasmaassisted pulsed laser deposited and atomic layer deposition, electron beam evaporation, DC magnetron sputtering, RF magnetron sputtering, and chemical deposition methods, namely, chemical bath deposition, chemical spray pyrolysis method, and sol-gel spin coating method.

\section{Materials and Method}

The TiZrN/TaZrN nanocomposite film is made by depositing titanium (Ti) and zirconium (Zr). The target and the tantalum $(\mathrm{Ta})$ are each $99.99 \%$ pure. The initial pressure was reduced to $4 \times 10^{-3} \mathrm{mbar}$ and the target was presprayed for 5 minutes to remove contaminants from the target surface before injection. A high purity reactive gas (99.999\%) is introduced into a vacuum chamber to form a thin TiZr/ $\mathrm{Ta}-\mathrm{Zr}$ film. Argon and nitrogen flow rates were adjusted to constant values throughout the investment. Table 1 shows the deposition parameters for the TiZrN coating [7]. Table 2 shows the chemical compositions of E19 steel.

\section{Results and Discussion}

3.1. Crystal Structure. Figures 1(a)-1(c) show the XRD shapes of samples S1 and S2 (TiZrN and TaZrN). The angle of incidence of X-rays was $0.5^{\circ}$ and angle 2 was scanned from $20^{\circ}$ to $59.983^{\circ}$. The 2 angles of the vertices were obtained by adjusting each vertex based on the Gaussian or Lorentz distribution hypothesis. The XRD models showed no additional phases not observed by the XRD. The crystalline level of TiZrN, i.e., (101), (101), (102), (103), and (200), was observed in the XRD pattern of sample S1 (Figure 1(a)). S2 sample models (Figure 1(b)) show that there were two phases in these bands, namely, TiZrN. As the current increased, the XRD intensity of level (101), (220), and (222) increased but decreased for level (200) [7]. The intensity of the plane (200) changed significantly, indicating a preferred orientation with maximum intensity. The development of the crystal structure is attributed to the additional energy of the deposition atoms on the substrate surface during the formation of the membrane, which leads to greater mobility of the Ad atom and therefore to greater crystalline of the membranes due to longer deposition time (60 minutes)
TABLE 1: Operating parameters for deposition of TiZrN/TaZrN thin film coating.

\begin{tabular}{lcc}
\hline Parameters & TiZrN & TaZrN \\
\hline Chamber base pressure & $4 \times 10^{-6} \mathrm{~m} \mathrm{bar}$ & $4 \times 10^{-6} \mathrm{~m}$ bar \\
Deposition pressure & $4 \times 10^{-3} \mathrm{~m} \mathrm{bar}$ & $4 \times 10^{-3} \mathrm{~m} \mathrm{bar}$ \\
Ar $: \mathrm{N}_{2}$ flow rate & $15: 3 \mathrm{sccm}$ & $15: 3 \mathrm{sccm}$ \\
Target distance & $70 \mathrm{~mm}$ & $70 \mathrm{~mm}$ \\
Substrate temperature & $200^{\circ} \mathrm{C}$ and $400^{\circ} \mathrm{C}$ & $200^{\circ} \mathrm{C}$ and $400^{\circ} \mathrm{C}$ \\
Interlayer & $60 \mathrm{~min}$ & $60 \mathrm{~min}$ \\
Ti (DC) and Ta (DC) & $100 \mathrm{~W}$ & $100 \mathrm{~W}$ \\
Zr (RF) & $100 \mathrm{~W}$ & $100 \mathrm{~W}$ \\
\hline
\end{tabular}

[8-13]. In addition, the observation is that the XRD $2 \Theta$ peaks shift at lower Bragg angles than in the standard TiN refraction model, which shows the extraction of the lattice by replacing $\mathrm{Zr}$ atoms with $\mathrm{Ti}$ atoms in the TiN structure. Full width at half maximum (FWHM) is 0.4047 and I/Io is 143.31. $\mathrm{Rp}$ is the calculated model $\mathrm{Rp}=72.4 \%$ and (200) the simple cubics present in the 45 present can have a base of multiple atoms. It has been found that the growth films consist of a simple cubic Ti- $\mathrm{Zr}-\mathrm{N}$ structure. The crystal system is tetragonal, and the space group is I $4 / \mathrm{mm}$ (139). Cell characteristics were estimated using XRD analysis for the $\mathrm{Ti}-\mathrm{Zr}-\mathrm{N}$ structure and carried out using a wavelength of $1.541874 \AA$.

It can be easily confirmed by XRD data from TaZrN samples (Figure 1(c)). The full diffraction spectrum shows the typical plane distance of the TaZrN structure. Figure 1(c) shows the spectra of samples $\mathrm{S} 1$ and $\mathrm{S} 2$, which correspond to two extreme cases in terms of composition (Table 3). These data show clear directions (111) and (200), although other diffractions are also observed. A physical property of the cal. density is $13.434 \mathrm{~g} / \mathrm{cm}^{3}$ wave length $1.5309 \AA$ to the FWHM 0.4047 and the $2 \theta$ is 41.81 (Sample S2 Figure 1(c)). The lack of separate diffraction groups for the two cubic grids indicates that the film studied is not an amphiphilic mixture of $\mathrm{Ta}$ and $\mathrm{Zr}$ due to the similarity between the two structural properties [14]. Figure 1(c) shows the grid parameters as a function. Tantalum material is represented by the composition $\mathrm{Ta} /(\mathrm{Zr}+\mathrm{Ta})$, which clearly shows that the stored tape is a step. The data range is $20^{\circ}-59.983^{\circ}$, and the wave length is $1.541874 \AA$ [4]. Cubic cell parameters was taken at $a=4.43400 \AA$ (sample S1 in Figure 1(c)).

\section{Scanning Electron Microscope}

Figures 2(a) and 2(b) show SEM cross-sectional images of the remaining samples at constant nitrogen and argon flow rates. Although the column is not visible in the sample remaining at $200^{\circ} \mathrm{C}$, the structure becomes clearer as the flow rate increases. The thickness of the TiZrN tape ranges from 500 to $1000 \mathrm{~nm}$ and decreases with increasing temperature within a fixed storage time of 60 minutes [9]. The storage time is calculated by dividing the thickness by the storage time. The difference between the storage rate and the temperature ratio is shown in Figure 2. When the constant nitrogen flow rate increases, the decrease in the supply of $\mathrm{Ti}$ and $\mathrm{Zr}$ atoms decreases with increasing temperature so that the rate of precipitation decreases. In this process, the high 
TABle 2: Chemical compositions of E19 steel.

\begin{tabular}{|c|c|c|c|c|c|c|}
\hline C (\%) & S (\%) & Si (\%) & $\mathrm{Cr}(\%)$ & Mn (\%) & Mo (\%) & P (\%) \\
\hline $0.35 \sim 0.45$ & $\leq 0.050$ & $0.10 \sim 0.35$ & $0.90 \sim 1.50$ & $0.50 \sim 0.80$ & $0.20 \sim 0.40$ & $\leq 0.035$ \\
\hline
\end{tabular}

Bold shows \% of chemical composition mixing in E19 steel.

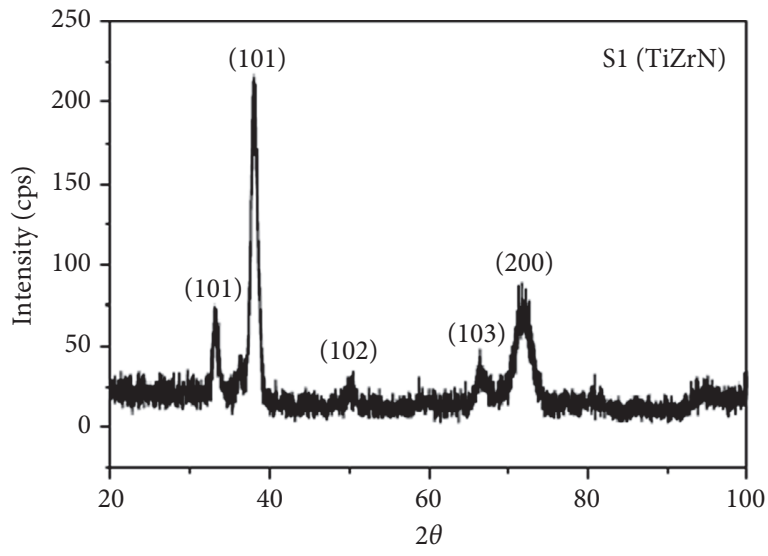

(a)

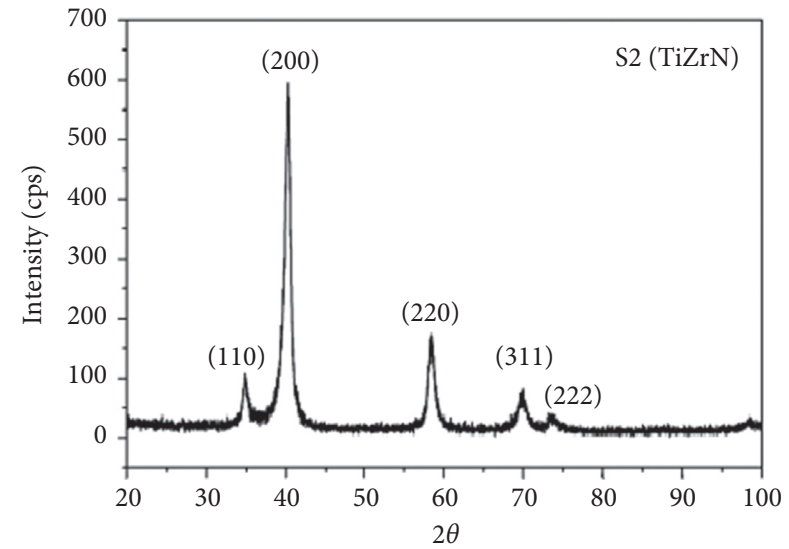

(b)

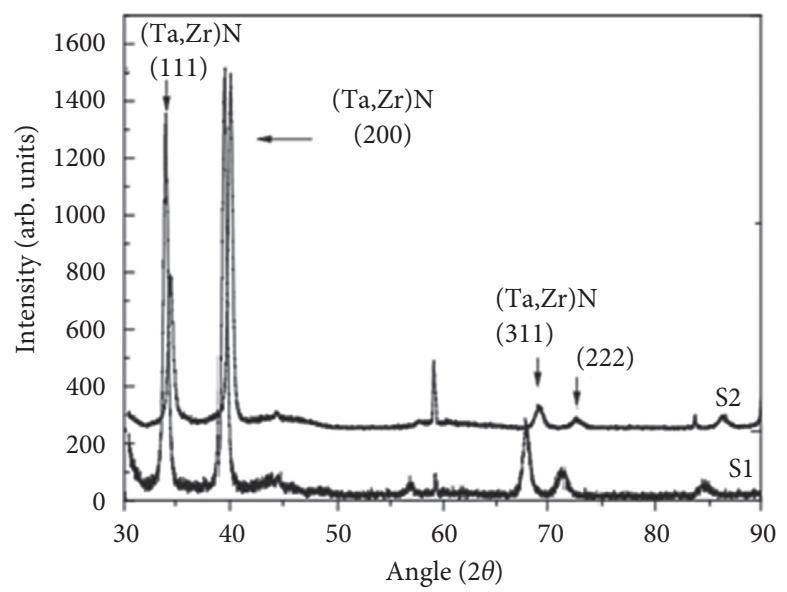

(c)

Figure 1: X-ray diffraction patterns of TiZrN/TaZrN films with different temperature contents.

TABLE 3: Surface roughness and hardness of coated material.

\begin{tabular}{|c|c|c|c|c|c|c|c|c|}
\hline $\begin{array}{l}\text { Coating } \\
\text { type }\end{array}$ & $\begin{array}{c}\text { Temperature } \\
\left({ }^{\circ} \mathrm{C}\right)\end{array}$ & $\begin{array}{l}\text { Hardness } \\
(\mathrm{GPa})\end{array}$ & $\begin{array}{c}\text { Surface } \\
\text { rougnness (Ra), } \\
\mathrm{nm}\end{array}$ & $\begin{array}{c}\text { Root mean } \\
\text { square }(\mathrm{Rq}) \text {, } \\
\mathrm{nm}\end{array}$ & $\begin{array}{c}\text { Smooth } \\
\text { Coefficient } \\
(\mathrm{Rku})\end{array}$ & $\begin{array}{l}\text { Sel. frequency } \\
\qquad(\mathrm{Hz})\end{array}$ & $\begin{array}{l}\text { Amplitude, } \\
\mathrm{nm}\end{array}$ & $\begin{array}{l}\text { Scan } \\
\text { rate } \\
(\mathrm{Hz}) \\
\end{array}$ \\
\hline \multirow[t]{2}{*}{ TiZrN } & $200(\mathrm{~S} 1)$ & 314 & 3.222 & 4.057 & 3.226 & \multirow{4}{*}{287.523} & \multirow{4}{*}{30.9} & \multirow{4}{*}{0.5} \\
\hline & $400(\mathrm{~S} 2)$ & 272.3 & 2.951 & 3.742 & 3.459 & & & \\
\hline \multirow[t]{2}{*}{ TaZrN } & 200 (S1) & 371.3 & 2.341 & 3.126 & 5.319 & & & \\
\hline & $400(\mathrm{~S} 2)$ & 286 & 2.359 & 3.186 & 6.040 & & & \\
\hline
\end{tabular}

Bold values indicate that AFM was used to examine the surface roughness and hardness of two materials. The frequency, amplitude, and scan rate were all kept at the same value.

$\mathrm{N}_{2}$ input reduces the concentration and energy of the $\mathrm{Ar}+$ ions in the plasma so that a lower Ta content is expected in the coating. Multilayer TaZrN coating is under various $R /$ $\mathrm{N}_{2}$ inputs [11]. There was an overlap of the columnar crystal structure and the $\mu \mathrm{m}$ residue formed under $R / N_{2}=15 / 3$ gave a smooth and abnormal image (see Figure 2(d)).
4.1. Atomic Force Microscope. The AFM images (auto probe NC microscope) in Figure 3 show a three-dimensional image of the morphology of the coated surface ( $5 \mu \mathrm{m}$ piezoelectric scanner with up to $5 \mu \mathrm{m}$ background scan area and up to 5 vertical scan area surface maps). Prepared sample temperatures were $200^{\circ} \mathrm{C}$ and $400^{\circ} \mathrm{C}$ (TiZrN/TaZrN). The scanning 


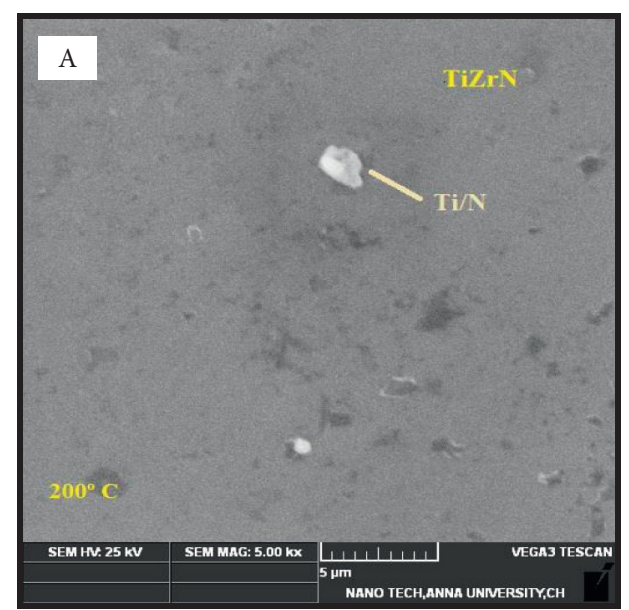

$\mathrm{S} 1(\mathrm{TiZrN})$ at $200^{\circ} \mathrm{C}$

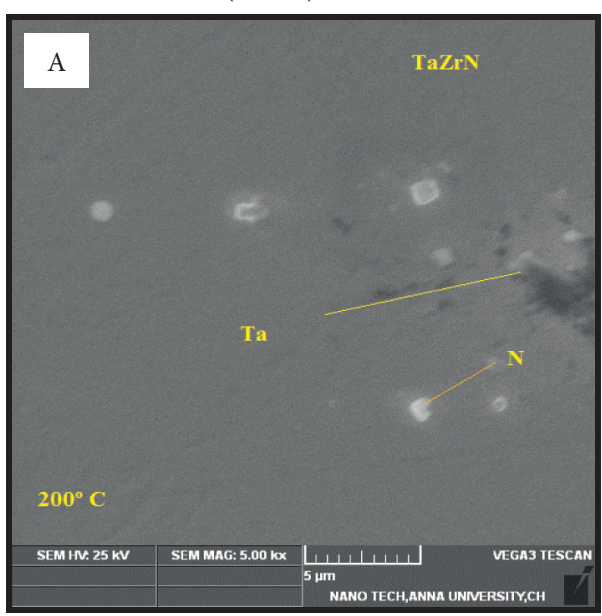

S1 (TaZrN) at $200^{\circ} \mathrm{C}$

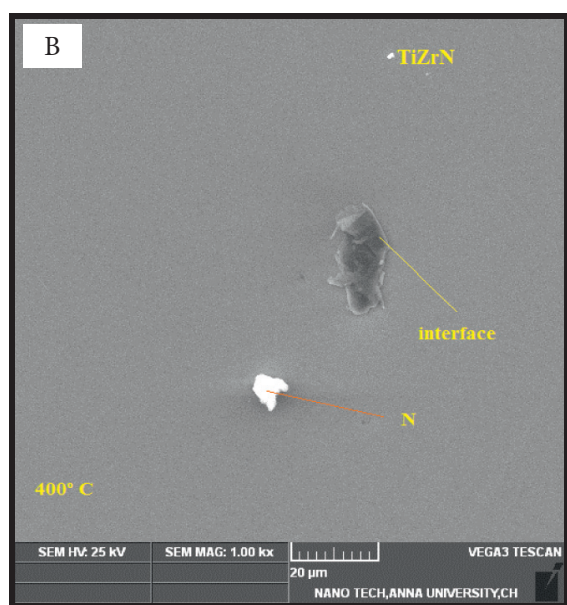

S2 (TiZrN) at $400^{\circ} \mathrm{C}$

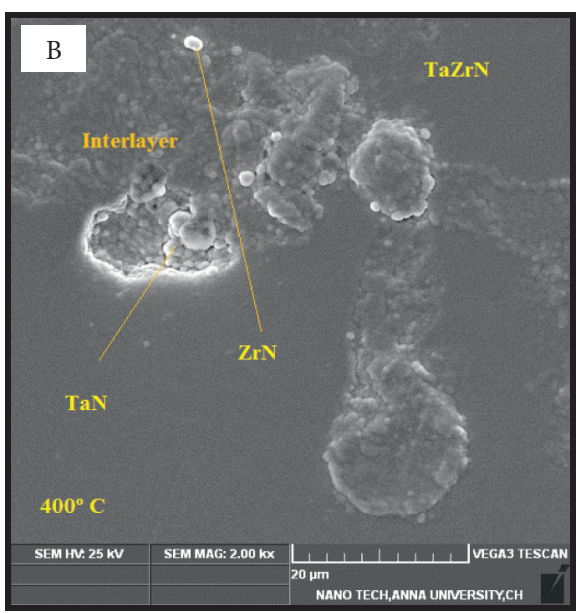

S1 (TaZrN) at $400^{\circ} \mathrm{C}$

Figure 2: Cross-section SEM image of TiZrN/TaZrN films with different temperatures: (a) S1 (TiZrN) at $200^{\circ} \mathrm{C}$, (b) S2 (TiZrN) at $400^{\circ} \mathrm{C}$, (c) S1 $(\mathrm{TaZrN})$ at $200^{\circ} \mathrm{C}$, and $(\mathrm{d}) \mathrm{S} 1(\mathrm{TaZrN})$ at $400^{\circ} \mathrm{C}$.

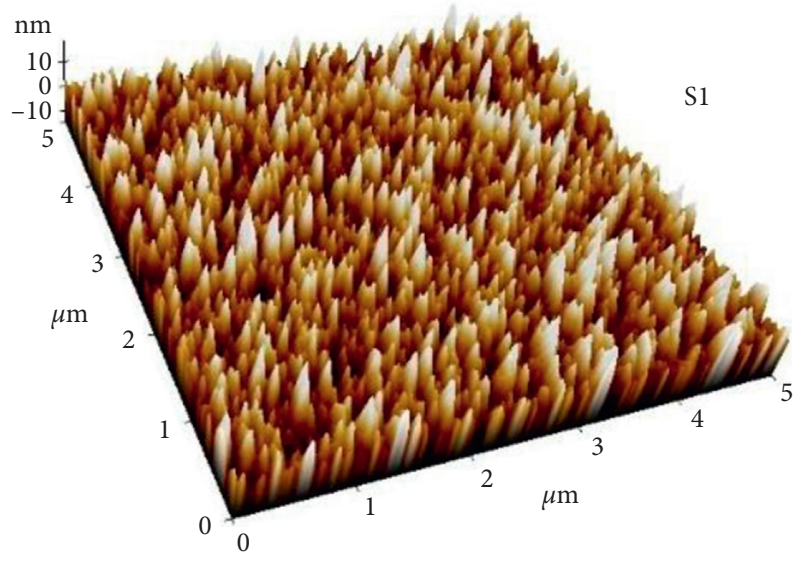

(a)

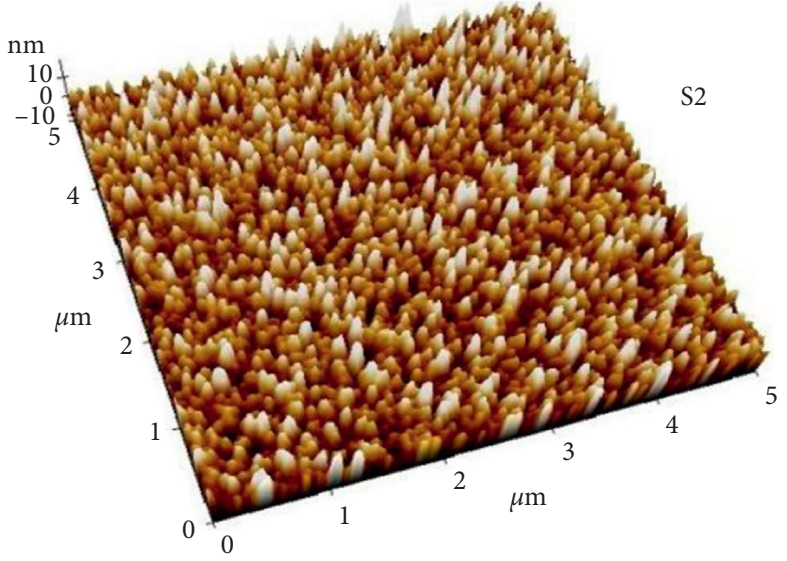

(b)

Figure 3: Continued. 


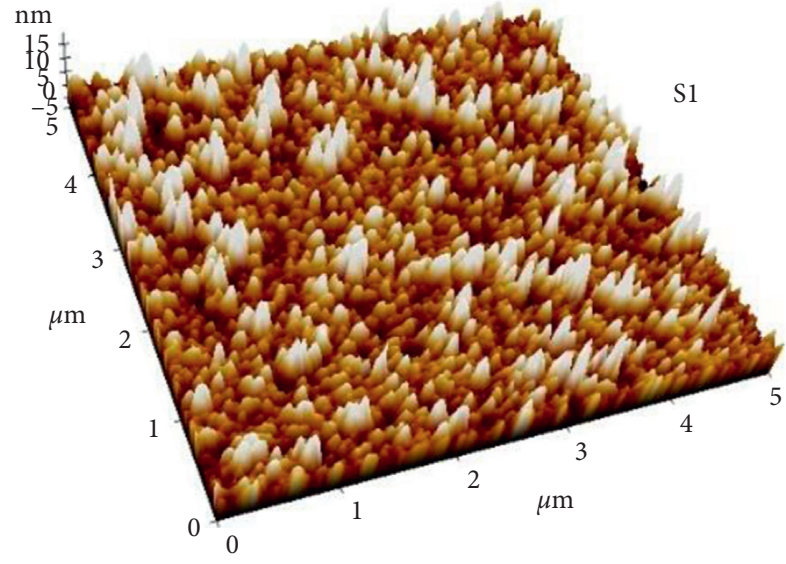

(c)

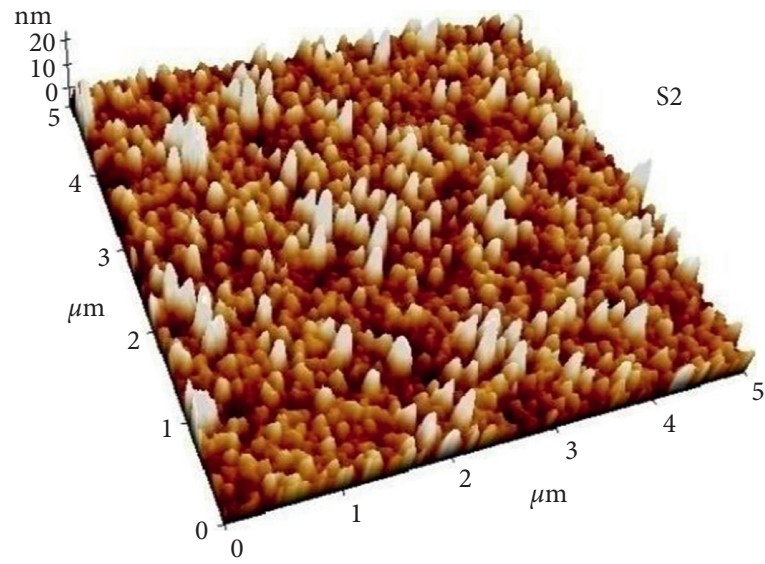

(d)

Figure 3: Surface morphology (3D view $5 \times 5 \mu \mathrm{m})$ of TiZrN/TzZrN deposited at different temperatures: ((a), (c)) $200^{\circ} \mathrm{C}$ and ((b), (d)) $400^{\circ} \mathrm{C}$.

rate, sel. frequency, and amplitude are commonly set by NC$\operatorname{AFM}(0.5 \mathrm{~Hz}, 287.52 \mathrm{E} 3 \mathrm{~Hz}$, and $30.9 \mathrm{~nm})$ Most grains of the same size and mixed grains are stored at $200^{\circ} \mathrm{C}$. All grains at $400^{\circ} \mathrm{C}$ look large on the surface, elongated, and unfolded. Gradually, increase the number of seeds by filling most of the triangular shapes. Adjust the particle volume to form a larger triangle [15-19]. The valley theme and open superstructure are seen on TaZrN. The original root of the sample is $\mathrm{Rq}$ $4.057,3.742 \mathrm{~nm}(\mathrm{TiZrN})$, and $3.126,3.186 \mathrm{~nm}(\mathrm{TaZrN})$, respectively (refer Figure 4). AFM shows average thickness 3.222, $2.951 \mathrm{~nm}$ for TiZrN and increasing value at TaZrN from 2.341 and $2.359 \mathrm{~nm}$ by increasing the temperature (refer Table 3 and Figure 5). The results are related to increased atomic energy and increased temperatures of titanium and tantalum. The thickness of the film is more affected by the Ti and Ta particles coming out of the target. The smooth coefficient (Rku) value increased by corresponding temperature of the given sample. The values are 3.226 and 3.459 for Ti-based and 5.319 and 6.040 for Tabased (refer Figure 4)

The Vickers hardness (Hv) followed to find the hardness in microscale of $\mathrm{Hv} 0.1$ for the test force $F=0.9807 \mathrm{~N}$ (Const. $X$ test force/surface area of indentation). The hardness of TaZrN/TiZrN samples was measured at three diagonal widths between the grooves. Calculate the mean and standard deviation of hardness and modulus:

$$
H v=0.102 \times \frac{2 F \operatorname{Sin} 136^{\circ} / 2}{d^{2}} \text {. }
$$

The concentration of titanium (isotope element) thermal expansion and electrical resistance is $8.6 \mu \mathrm{m} / \mathrm{m} . \mathrm{k}$ at $25^{\circ} \mathrm{C}$ and $420 \mathrm{n} \Omega \mathrm{m}$ at $20^{\circ} \mathrm{C}$, mechanical stability in that pure target was $\mu=0.32, \quad E=116 \mathrm{GPa}, \quad \tau=44 \mathrm{GPa}$, and $\rho=4.506 \mathrm{~g} / \mathrm{cm}^{3}$. Tantalum has a low thermal and electrical resistance when compared to Ti because of its bcc and tetragonal structure $(\alpha-\mathrm{Ta}, \beta-\mathrm{Ta})$. The mechanical characteristics of pure Ta are $=0.34, \quad E=186 \mathrm{GPa}, \quad \tau=186 \mathrm{GPa}$, and $\rho=16.69 \mathrm{~g} / \mathrm{cm}^{3}$. Common layer of $\mathrm{Zr}$ (91.22 atomic mass unit)-based target has the density and melting point of $\rho=16.49 \mathrm{gms} / \mathrm{cc}$ and

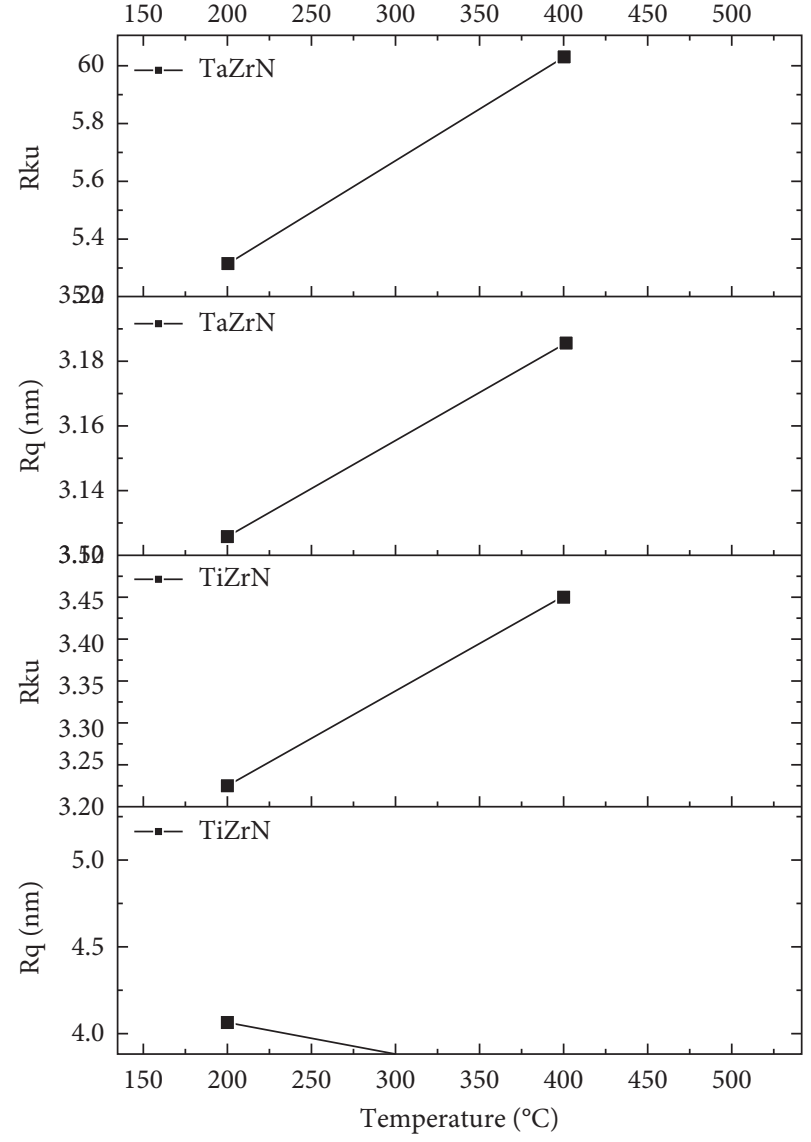

FIgURE 4: Temperature vs root mean square (Rq) and smooth coefficient (Rku).

$1852^{\circ} \mathrm{C}$. Multilayer coating hardness and modules are between single TaZrN/TiZrN layers. This means the law of mixing in mechanical behavior. The multilayered structure of this one-component zirconium nitride system helps improve hardness and modulus [20]. Figure 6 shows the hardness of the film and the relationship between tantalum and zirconium materials. The hardness of the film consisting 

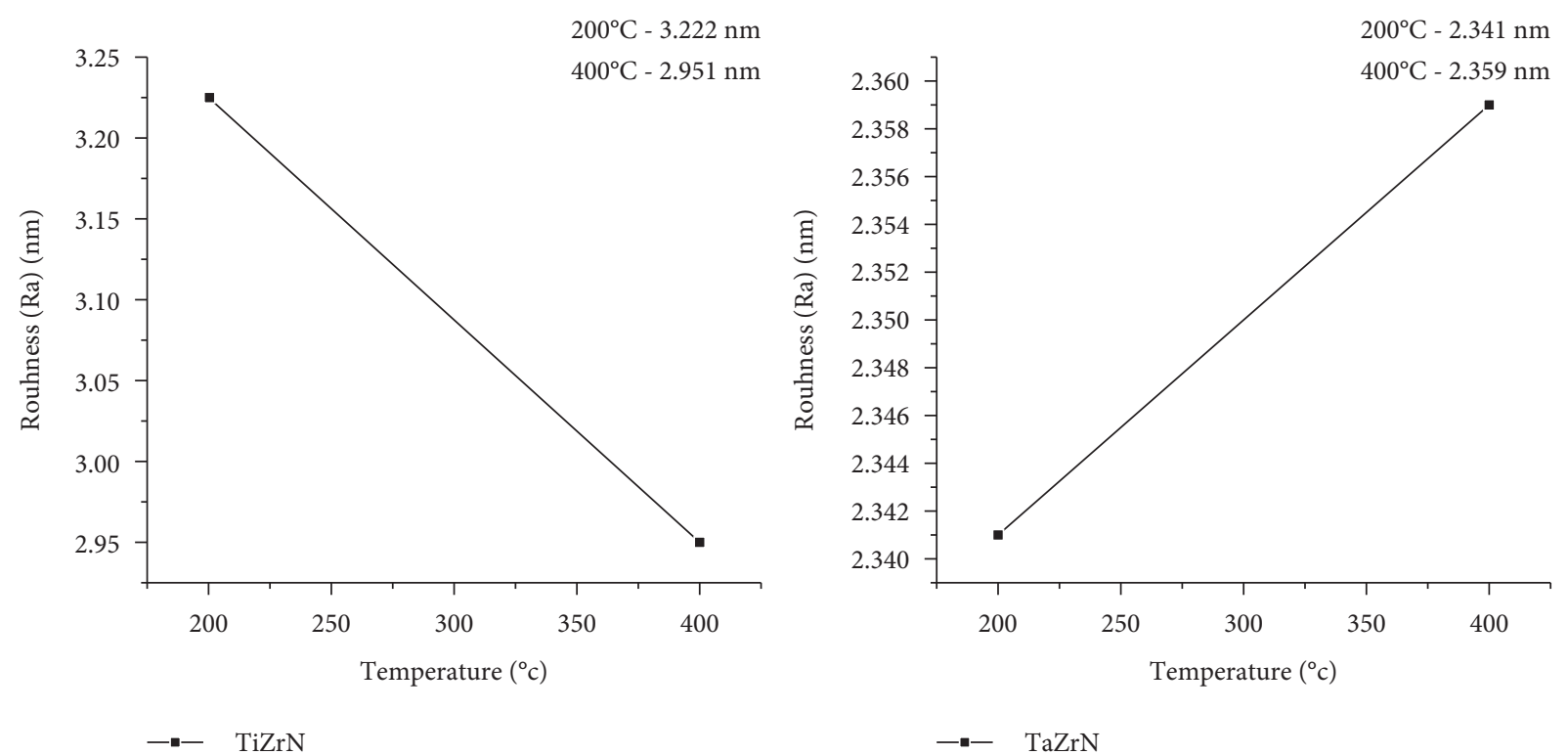

Figure 5: Temperature vs Avg. roughness (Ra).
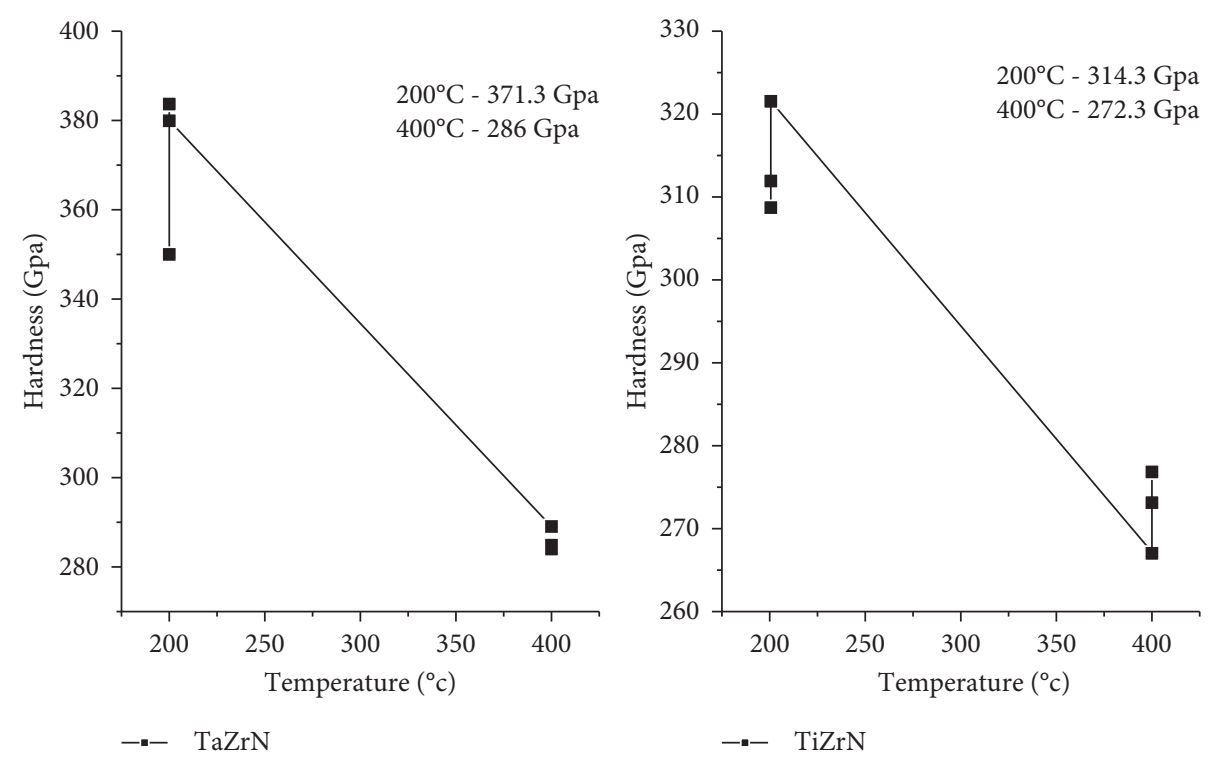

FIgURE 6: Temperature vs hardness (GPa).

TABLE 4: Details of testing parameters in constant humidity condensation atmosphere test (ref. 6270:2005 (E)).

Humidity

Temperature

Pr. of air for atomizing

Mixed with brine ( $5 \%$ of sodium chloride, $1 \%$ of magnesium chloride, and deionized water $94 \%$

$\mathrm{pH}$ of the solution

$\mathrm{pH}$ improvement

Some service providers
$98 \%$ when measured with a hygrometer during a test

35 to 45 degrees Celsius

Infinitely variable from 2 to 3 bar with pressure regulator

For 1 liter of solution

Maintained at 7.5 by the addition of a buffer solution

Measured every 8 hours

Tied with plastic wire and hanged on the hanger 
TABLE 5: Important parameters evaluated from the coated samples of TiZrN/TaZrN tested in salt spray ASTM B-117 (ISO $9227: 2017$ (CASS TEST)).

\begin{tabular}{|c|c|c|c|}
\hline $\mathrm{pH}$ & Samples & $\begin{array}{l}\text { Temp. of } \\
\text { solution }\end{array}$ & Concentration \\
\hline $\begin{array}{l}3.13 \text { to } \\
3.18\end{array}$ & $\begin{array}{c}\operatorname{TiZrN}\left(200^{\circ} \mathrm{C} \text { and }\right. \\
\left.400^{\circ} \mathrm{C}\right) \\
\operatorname{TaZrN}\left(200^{\circ} \mathrm{C} \text { and }\right. \\
\left.400^{\circ} \mathrm{C}\right)\end{array}$ & $35.3^{\circ} \mathrm{C} \pm 2^{\circ} \mathrm{C}$ & $\begin{array}{l}\text { Sodium chloride }\left(5.2 \% \text { of } \mathrm{NaCl}+0.26 \mathrm{~g} \text { of } \mathrm{CuCl} 2.2 \mathrm{H}_{2} \mathrm{O}+\text { acetic acid to maintain }\right. \\
\qquad \mathrm{pH})-52-53 \mathrm{~g} / \mathrm{l}\end{array}$ \\
\hline 6.7 to 7 & $\begin{array}{c}\operatorname{TiZrN}\left(200^{\circ} \mathrm{C} \text { and }\right. \\
\left.400^{\circ} \mathrm{C}\right) \\
\operatorname{TaZrN}\left(200^{\circ} \mathrm{C} \text { and }\right. \\
\left.400^{\circ} \mathrm{C}\right)\end{array}$ & $49.5^{\circ} \mathrm{C} \pm 2^{\circ} \mathrm{C}$ & Pr. of compressed air $15 \mathrm{psi}$, collection of sol. Per hr $1.3-1.5 \mathrm{ml}$ \\
\hline
\end{tabular}
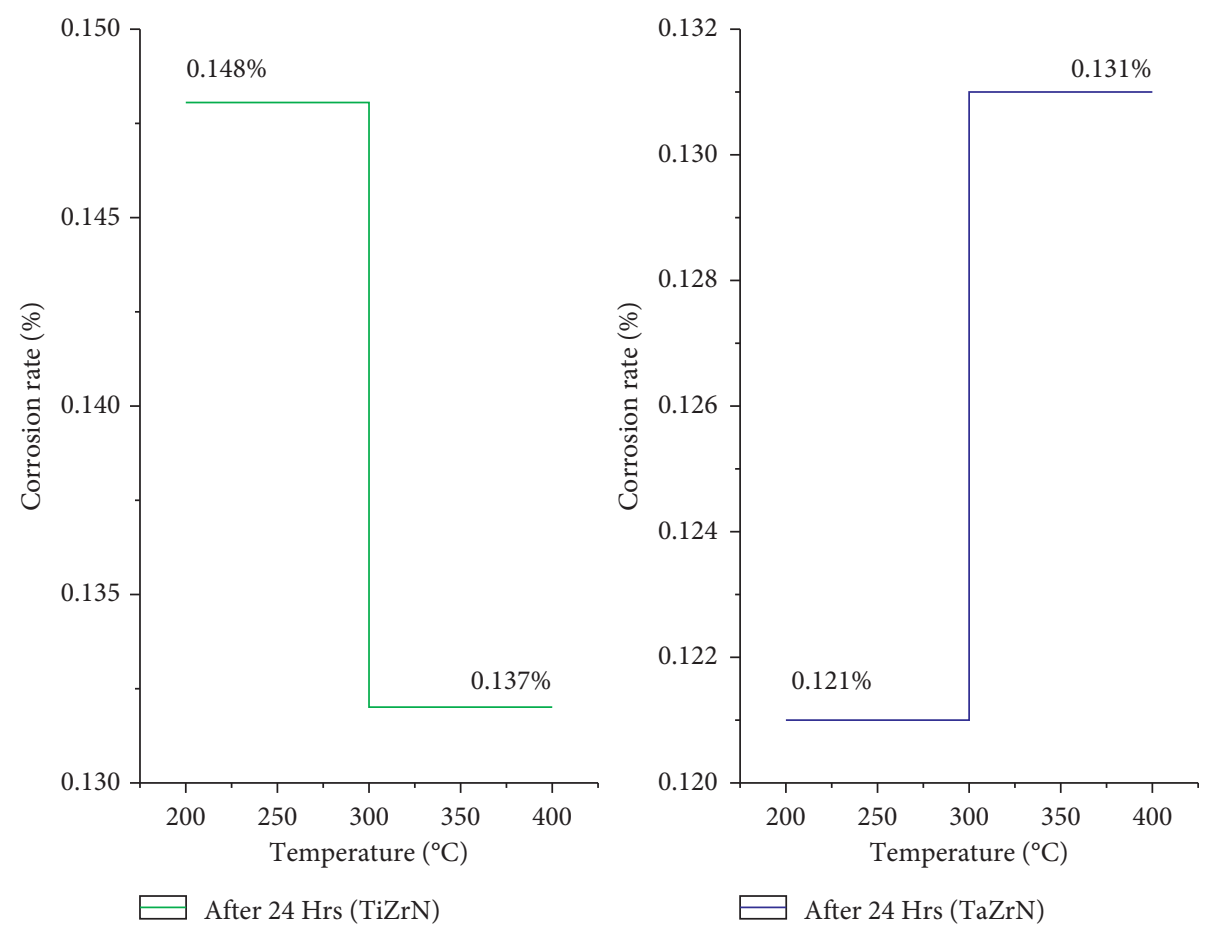

Figure 7: Temperature vs corrosion rate (\%) for humidity test.

of Ta (Figure 6, TaZrN) gradually increases to $371.3 \mathrm{GPa}$. This is about 1.8 times the evenly collected diagonal length of $\mathrm{ZrN}$ in the same case. Due to the slight change in the load, the value of the hardness measured under the load has not changed $[7,21]$. Due to the hard crystalline phase of TIN, the highest hardness and modulus of approximately 4,314.3 GPa were found in the C-type layer, respectively [11]. The hardness value decreased due to the temperature value increased for $\mathrm{Ta}$ and Ti-based and the highest value produced at $200^{\circ} \mathrm{C}$ in the density of $13.434 \mathrm{~g} / \mathrm{cm}^{3}$ for TaZrN and $6.82200 \mathrm{~g} / \mathrm{cm} 3$ for TiZrN.

\section{Corrosion Behavior}

Salt spray technique and humidity fog test made it possible to investigate the corrosion behavior of the TiZrN/TaZrN coating on AISI 4140 steel [11]. This measurement initially initiated the investigation of corrosion behavior. The fog humidity test is shown in Table 4 . Then, the salt spray samples were polarized in sodium chloride $(5.2 \%$ of $\mathrm{NaCl}+0.26$ g of $\mathrm{CuCl}_{2} \cdot 2 \mathrm{H}_{2} \mathrm{O}+$ acetic acid to maintain $\mathrm{pH}$ ) - 52-53 g/l, pressure of compressed air $15 \mathrm{psi}$, and collection of solution per hour $1.3-1.5 \mathrm{ml}$ at air saturated at various $\mathrm{pH}$ 3.13 to 3.18 and 6.7 to 7 (Table 5). Effect of TiZrN/TaZrN coatings with anticorrosive behavior 7 shows the polarization curves for various temperature samples with the studied changes in surface roughness [22-28]. The important parameters estimated from the polarization curves are listed in Table 4. It is clear that the multilayer coating significantly affects the corrosion properties of AISI 4140 steel, in particular the corrosion current density (Icorr). In comparison with the corrosion rate of TiZrN/TaZrN samples, the corrosion rate significantly increases with surface roughness (Table 3 and Figure 7). The corrosion rate of humidity test carried temperature increases with increase in corrosion rate of $0.121-0.131 \%$ for $\mathrm{TaZrN}$ and surface roughness slightly affects the corrosion rate of $0.131-0.148 \%$ for TiZrN (Figure 7). This is because a high degree of irritation leads to 
more defects in the coating, as well as a smaller sample with fuller coverage. Concentration in $5.2 \%$ of $\mathrm{NaCl}$ at air saturated at $\mathrm{pH} 7$ exhibited better corrosion resistance. The result of a humidity test at $44^{\circ} \mathrm{C} \pm 2^{\circ} \mathrm{C}$ with a $\mathrm{pH}$ of 7.5 was that no rust formed after 24 hours [14, 29-36].

\section{Conclusion}

Ti-Zr-N/TaZrN coating was synthesized by the method of RF/ DC magnetron sputtering by $99.99 \%$ purity of targets. With increase of current, the XRD intensities of (101) plane (220) and (222) plane were increased. The Ti-Zr-N/TaZrN coating was done with an XRD intensity of 0.4047 at TiZrN (FWHM), space group I 4/mm (139), and a tetragonal crystal system with cell parameters of $a=4.01900 \AA$ and $c=9.57700 \AA$. The data revealed strong (111) and (200) preferred orientations though other diffraction lines were also observed at TaZrN. A physical property of the cal. density is $13.434 \mathrm{~g} / \mathrm{cm}^{3}$ (FWHM) which is 0.4047 and the $2 \theta$ value is 59.30 (1.5571 $\AA$ ) space group which is Fm-3m (225) and the crystal system is cubic [37-44]. The surface roughness of substrate of TiZrN/TaZrN film during corrosion testing is the corrosion rate increased with increasing surface roughness of substrate. Concentration in 5.2\% of $\mathrm{NaCl}$ at air saturated at $\mathrm{pH} 7$ exhibited better corrosion resistance. The corrosion rate of humidity test carried temperature increases with increase in corrosion rate of $0.121-0.131 \%$ for TaZrN and surface roughness slightly affects the corrosion rate of $0.131-0.148 \%$ for TiZrN (Figure 7 ). The hardness of the film (Figure 6, TaZrN) will gradually increase with the Ta value of $371.3 \mathrm{GPa}$. A highest hardness and modulus are around $314.3 \mathrm{GPa}$ (Figure 6, TiZrN). The hardness value decreased due to the temperature value increased for $\mathrm{Ta}$ and Ti-based and the highest value produced at $200^{\circ} \mathrm{C}$ in the density of $13.434 \mathrm{~g} / \mathrm{cm}^{3}$ for TaZrN and $6.82200 \mathrm{~g} /$ $\mathrm{cm}^{3}$ for TiZrN. AFM are $0.5 \mathrm{~Hz}, 287.52 \mathrm{E} 3 \mathrm{~Hz}$, and $30.9 \mathrm{~nm}$. The compact morphology of $200^{\circ} \mathrm{C}$-stored samples and $400^{\circ} \mathrm{C}$ stored whole grains tends to be larger and longer and spread over the surface $[37,38,45-51]$. The particle size gradually increases in a triangular pattern. AFM shows that with increasing temperature, the average thickness continuously decreases from 3.222 to $2.951 \mathrm{~nm}$ for TiZrN and the value at TaZrN increases from 2.341 to $2.359 \mathrm{~nm}$ by increasing the temperature (see Table 3 and Figure 5). Interatomic energy and temperature of titanium and tantalum increased. It also affects the film thickness of some off-target $\mathrm{Ti}$ and $\mathrm{Ta}$ particles $[4,5,39,52-55]$. The transported TiZr NSEM film thickness ranged from 500 to $1000 \mathrm{~nm}$, which decreased with increasing temperature velocity over a 60-minute deposition time (Figure 2). This is probably due to the decrease in the number of $\mathrm{Ti}$ and $\mathrm{Zr}$ atoms with a constant increase in nitrogen flow. Precipitation decreases as the temperature rises. This will reduce the accumulation rate of $\mathrm{Ar} / N=15 / 3$ [42].

\section{Data Availability}

The data used to support the findings of this study are included within the article. Further data or information is available from the corresponding author upon request.

\section{Conflicts of Interest}

The authors declare that there are no conflicts of interest regarding the publication of this article.

\section{Acknowledgments}

This project was supported by the Deanship of Scientific Research at Prince Sattam Bin Abdulaziz University under the research project \#2020/01/17093.

\section{References}

[1] S. M. Aouadi, P. Filip, and M. Debessai, "Characterization of tantalum zirconium nitride sputter-deposited nanocrystalline coatings," Surface and Coatings Technology, vol. 187, no. 2-3, pp. 177-184, 2004.

[2] J. A. Woollam, Guide to Using WVASE32, Woollam Company, Lincoln, NE, 1997.

[3] R. E. Hummel and P. Wißmann, Handbook of Optical Properties, Optics of Small Particles, Interfaces, and Surfaces, CRC Press, vol. 2, p. 164, New York, 1995.

[4] D. A. Jones, Principles and Prevention of Corrosionpp. 292-304, Prentice-Hall, London, 2nd ed. edition, 1996.

[5] C. Liu, A. Leyland, S. Lyon, A. Matthews, and A. Matthews, "An a.c. impedance study on PVD CrN-coated mild steel with different surface roughnesses," Surface and Coatings Technology, vol. 76-77, pp. 623-631, 1995.

[6] F. Wootten, Optical Properties of Solids, Academic Press, New York, 1972.

[7] R. Hariharan, R. Raja, and R. J. Golden RenjithNimal, "Investigation of mechanical and tribological properties of titanium nitride deposited on low carbon steel by RF magnetron sputtering," Journal of Critical Reviews, vol. 7, no. 04, pp. 324-328, 2020.

[8] P. Patsalas and S. Logothetidis, "Interface properties and structural evolution of TiN/Si and TiN/GaN heterostructures," Journal of Applied Physics, vol. 93, no. 2, pp. 989-998, 2003.

[9] C. Kittel, Introduction to Solid State Physicsp. 159, 7th ed. edition, Wiley, New York, NY, 1996.

[10] D.-Y. Wang, C.-L. Chang, C.-H. Hsu, and H.-N. Lin, "Synthesis of (Ti, $\mathrm{Zr}) \mathrm{N}$ hard coatings by unbalanced magnetron sputtering," Surface and Coatings Technology, vol. 130, no. 1, pp. 64-68, 2000.

[11] R. Hariharan, R. Raja, and S. Vasu, "Mechanical and tribologicalbehaviour of thin TaN coating produced on AISI 1018 substrate by DC magnetron sputtering," IJRTE, vol. 7, no. 6S2, pp. 591-598, 2019.

[12] J.-L. Ruan, J.-L. Huang, H.-H. Lu, J. S. Chen, and D.-F. Lii, "Effects of the Ta content on the microstructure and electrical property of reactively sputtered TaxZr $1-\mathrm{xN}$ thin films," Thin Solid Films, vol. 519, no. 15, pp. 4987-4991, 2011.

[13] L. Li, E. Niu, G. Lv et al., "Synthesis and electrochemical characteristics of Ta-N thin films fabricated by cathodic arc deposition," Applied Surface Science, vol. 253, no. 16, pp. 6811-6816, 2007.

[14] R. Hariharan, R. Raja, and R. J. Golden RenjithNimal, "Characteristic of $\mathrm{h}$ on mild steel/aln cermet selective surfaces deposited by Rf magnetron sputtering," Journal of Critical Reviews, vol. 7, no. 04, pp. 319-323, 2020.

[15] D. A. Neamen, An Introduction to Semiconductor Devices, McGraw-Hill, New York, 2006. 
[16] M. Saib, J. C. Francois, P. Gravier, M. Sigrist, L. Argeme, and O. Cerclier, "Resistivity and hall effect of reactively zirconium nitride films," Solid State Communications, vol. 58, no. 6, pp. 385-388, 1986.

[17] L. E. Koutsokeras, N. Hastas, S. Kassavetis et al., "Electronic properties of binary and ternary, hard and refractory transition metal nitrides," Surface and Coatings Technology, vol. 204, no. 12-13, pp. 2038-2041, 2010.

[18] G. M. Matenoglou, L. E. Koutsokeras, and P. Patsalas, "Plasma energy and work function of conducting transition metal nitrides for electronic applications," Applied Physics Letters, vol. 94, no. 15, Article ID 152108, 2009.

[19] E. Guilmeau, D. Bérardan, C. Simon et al., "Tuning the transport and thermoelectric properties of In2O3 bulk ceramics through doping at In-site," Journal of Applied Physics, vol. 106, no. 5, Article ID 053715, 2009.

[20] T. Schuler and M. A. Aegerter, "Optical, electrical and structural properties of sol gel $\mathrm{ZnO}$ :Al coatings," Thin Solid Films, vol. 351, no. 1-2, pp. 125-131, 1999.

[21] K.-Y. Liu, J.-W. Lee, and F.-B. Wu, "Fabrication and tribological behavior of sputtering TaN coatings," Surface and Coatings Technology, vol. 259, pp. 123-128, 2014, SCT-19279.

[22] B. Bushan, B. K. Gupta, Handbook of Tribology, Vol. 57, McGraw-Hill, , New York, 1991.

[23] S. K. Kim and B. C. Cha, "Deposition of tantalum nitride thin films by D.C. magnetron sputtering," Thin Solid Films, vol. 475, no. 1-2, pp. 202-207, 2005.

[24] Y. X. Leng, H. Sun, P. Yang et al., "Biomedical properties of tantalum nitride films synthesized by reactive magnetron sputtering," Thin Solid Films, vol. 398-399, pp. 471-475, 2001.

[25] C.-S. Shin, Y.-W. Kim, D. Gall, J. E. Greene, and I. Petrov, "Phase composition and microstructure of polycrystalline and epitaxial TaNx layers grown on oxidized $\mathrm{Si}(001)$ and $\mathrm{MgO}(001)$ by reactive magnetron sputter deposition," Thin Solid Films, vol. 402, no. 1-2, pp. 172-182, 2002.

[26] G. R. Lee, H. Kim, H. S. Choi, and J. J. Lee, "Superhard tantalum-nitride films formed by inductively coupled plasmaassisted sputtering," Surface and Coatings Technology, vol. 201, no. 9-11, pp. 5207-5210, 2007.

[27] Y.-I. Chen, B.-L. Lin, Y.-C. Kuo, J.-C. Huang, L.-C. Chang, and Y.-T. Lin, "Preparation and annealing study of $\mathrm{TaNx}$ coatings on WC-Co substrates," Applied Surface Science, vol. 257, no. 15, pp. 6741-6749, 2011.

[28] Y. Kang, C. Lee, and J. Lee, "Effects of processing variables on the mechanical properties of $\mathrm{Ta} / \mathrm{TaN}$ multilayer coatings," Materials Science and Engineering: B, vol. 75, no. 1, pp. 17-23, 2000.

[29] P.-L. Sun, C.-Y. Su, T.-P. Liou, C.-H. Hsu, and C.-K. Lin, "Mechanical behavior of TiN/CrN nano-multilayer thin film deposited by unbalanced magnetron sputter process," Journal of Alloys and Compounds, vol. 509, no. 6, pp. 3197-3201, 2011.

[30] Y.-W. Lin, C.-W. Lu, G.-P. Yu, and J.-H. Huang, "Structure and properties of nanocrystalline (TiZr) xN1-xThin films deposited by DC unbalanced magnetron sputtering," Journal of Nanomaterials, vol. 2016, pp. 1-12, Article ID 2982184, 2016.

[31] A. S. Korhonen, J. M. Molarius, I. Penttinen, and E. Harju, "Hard transition metal nitride films deposited by triode ion plating," Materials Science and Engineering, vol. 105-106, no. 2, pp. 497-501, 1988.

[32] L. P. Ward, K. N. Strafford, C. Subramanian, and T. P. Wilks, "Observations on the structure, hardness and adhesion properties of a selection of multicomponent refractory element nitride coatings," Journal ofMaterials Processing Technology, vol. 56, no. 1-4, pp. 375-384, 1996.
[33] L. A. Donohue, J. Cawley, and J. S. Brooks, "Deposition and characterisation of arc-bond sputter TixZryN coatings from pure metallic and segmented targets," Surface and Coatings Technology, vol. 72, no. 1-2, pp. 128-138, 1995.

[34] V. V. Uglov, V. M. Anishchik, V. V. Khodasevich et al., "Structural characterization and mechanical properties of TiZr-N coatings, deposited by vacuum arc," Surface and Coatings Technology, vol. 180-181, pp. 519-525, 2004.

[35] P. J. Kelly and R. D. Arnell, "Magnetron sputtering: a review of recent developments and applications," Vacuum, vol. 56, no. 3, pp. 159-172, 2000.

[36] S. Chinsakolthanakorn, A. Buranawong, N. Witit-anun, S. Chaiyakun, and P. Limsuwan, "Characterization of nanostructured TiZrN thin films deposited by reactive DC magnetron Co-sputtering," Procedia Engineering, vol. 32, pp. 571-576, 2012.

[37] E. W. Niu, L. Li, G. H. Lv et al., "Characterization of Ti-Zr-N films deposited by cathodic vacuum arc with different substrate bias," Applied Surface Science, vol. 254, no. 13, pp. 3909-3914, 2008.

[38] D. Y. Wang, C. L. Chang, C. H. Hsu, and H. N. Lin, "Synthesis of $(\mathrm{Ti}, \mathrm{Zr}) \mathrm{N}$ hard coatings by unbalanced magnetron sputtering," Surface and Coatings Technology, vol. 130, pp. 64-68, 2000.

[39] C.-P. Liu and H.-G. Yang, "Systematic study of the evolution of texture and electrical properties of $\mathrm{ZrNx}$ thin films by reactive DC magnetron sputtering," Thin Solid Films, vol. 444, no. 1-2, pp. 111-119, 2003.

[40] P. W. Shum, W. C. Tam, K. Y. Li, Z. F. Zhou, and Y. G. Shen, "Mechanical and tribological properties of titanium-aluminium-nitride films deposited by reactive close-field unbalanced magnetron sputtering," Wear, vol. 257, no. 9-10, pp. 1030-1040, 2004.

[41] K. Singh, P. K. Limaye, N. L. Soni, A. K. Grover, R. G. Agrawal, and A. K. Suri, "Wear studies of (Ti-Al)N coatings deposited by reactive magnetron sputtering," Wear, vol. 258, no. 11-12, pp. 1813-1824, 2005.

[42] K. H. Chung, G. T. Liu, J. G. Duh, and J. H. Wang, "Biocompatibility of a titanium-aluminum nitride film coating on a dental alloy," Surface and Coatings Technology, vol. 188-189, pp. 745-749, 2004.

[43] E. Lugscheider, O. Knotek, C. Barimani, T. Leyendecker, O. Lemmer, and R. Wenke, "PVD hard coated reamers in lubricant-freecutting," Surface and Coatings Technology, vol. 112, pp. 146-151, 1999.

[44] J. V. Ramana, S. Kumar, C. David, and V. S. Raju, "Structure, composition and microhardness of $(\mathrm{Ti}, \mathrm{Zr}) \mathrm{N}$ and $(\mathrm{Ti}, \mathrm{Al}) \mathrm{N}$ coatings prepared by DC magnetron sputtering," Materials Letters, vol. 58, no. 20, pp. 2553-2558, 2004.

[45] V. V. Uglov, V. M. Anishchik, S. V. Zlotski, and G. Abadias, "The phase composition and stress development in ternary Ti$\mathrm{Zr}-\mathrm{N}$ coatings grown by vacuum arc with combining of plasma flow," Surface and Coatings Technology, vol. 200, pp. 6389-6394, 2006.

[46] M. B. Takeyama, T. Itoi, E. Aoyagi, and A. Noya, "Diffusion barrier properties of nano-crystalline TiZrN films in $\mathrm{Cu} / \mathrm{Si}$ contact systems," Applications of Surface Science, vol. 216, pp. 181-186, 2003.

[47] J. A. Thornton, "Influence of apparatus geometry and deposition conditions on the structure and topography of thick sputtered coatings," J VacSciTechnol, vol. 11, pp. 666-670, 1974.

[48] C. Keawhan, P. Wongpanya, N. Witit-Anun, and P. Songsiriritthigul, "Corrosion behavior of AISI 4140 steel 
surface coated by physical vapor deposition," Journal of Metals, Materials and Minerals, vol. 22, no. 1, pp. 69-76, 2012.

[49] S. D. Chyou and H. C. Shih, "The effect of nitrogen on the corrosion of plasma-n 4140 steel," Corrosion, vol. 47, no. 1, pp. 31-34, 1991.

[50] H. J. Grabke, "High nitrogen steels. The role of nitrogen in the corrosion of iron and steels," ISIJ International, vol. 36, no. 7, pp. 777-786, 1996.

[51] P. F. Hui, H. H. Cheng, K. L. Jung, and H. S. Yih, "Effects of PVD sputtered coating on the corrosion resistance of AISI304 stainless steel," Materials Science and Engineering, vol. 347, no. 1-2, pp. 123-129, 2003.

[52] R. Walter and M. B. Kannan, "Influence of surface roughness on the corrosion behaviour of magnesium alloy," Materials \& Design, vol. 32, no. 4, pp. 2350-2354, 2011.

[53] S. H. Ahn, J. H. Yoo, Y. S. Choi, J. G. Kim, and J. G. Han, "Corrosion behavior of PVD-grown WC-(Til-x alx)N films in a $3.5 \mathrm{wt} \% \mathrm{NaCl}$ solution," Surface and Coatings Technology, vol. 162, no. 2-3, pp. 212-221, 2003.

[54] Y.-W. Lin, J.-H. Huang, and G.-P. Yu, "Effect of nitrogen flow rate on properties of nanostructured TiZrN thin films produced by radio frequency magnetron sputtering," Thin Solid Films, vol. 518, no. 24, pp. 7308-7311, 2010.

[55] S. Hogmark, S. Jacobson, and M. Larsson, "Design and evaluation of tribological coatings," Wear, vol. 246, no. 1-2, pp. 20-33, 2000. 